\title{
Fluid Extract Dosage Form
}

National Cancer Institute

\section{Source}

National Cancer Institute. Fluid Extract Dosage Form. NCI Thesaurus. Code C68991.

A solution or suspension distillate composed of active and/or inert ingredient(s) extracted from plant or animal matter and alcohol as the solvent and/or preservative. Fluid extract is prepared by percolation and subsequent evaporation such that the ing redient in each milliliter of the fluid extract is equivalent to $1 \mathrm{gram}$ of the dried plant or animal derived matter. 